\title{
Occurrence of structural polymorphism and supernumerary chromosomes in a population of Parodon nasus (Parodontidae)
}

\author{
Angélica Alves de Paula, Helen Alves Penha, Vitor Antonio Delai, Lucia \\ Giuliano-Caetano \& Ana Lúcia Dias
}

To cite this article: Angélica Alves de Paula, Helen Alves Penha, Vitor Antonio Delai, Lucia Giuliano-Caetano \& Ana Lúcia Dias (2017) Occurrence of structural polymorphism and supernumerary chromosomes in a population of Parodon nasus (Parodontidae), Caryologia, 70:3, 200-205, DOI: 10.1080/00087114.2017.1318503

To link to this article: https://doi.org/10.1080/00087114.2017.1318503

曲 Published online: 23 May 2017.

Submit your article to this journal ๔

Џ Article views: 37

View Crossmark data ¿ 


\title{
Occurrence of structural polymorphism and supernumerary chromosomes in a population of Parodon nasus (Parodontidae)
}

\author{
Angélica Alves de Paulaa, Helen Alves Penha ${ }^{b}$, Vitor Antonio Delaia, Lucia Giuliano-Caetano ${ }^{a}$ (D) and \\ Ana Lúcia Dias ${ }^{\mathrm{a}}$
}

aDepartamento de Biologia Geral, CCB, Universidade Estadual de Londrina, Londrina, Brazil; 'baboratório de Bioquímica e Biologia Molecular, UNESP/FCAV, São Paulo, Brazil

\begin{abstract}
The family Parodontidae is a small group of fish that has distinct morphological differences. Despite its conserved diploid number, structural cytogenetic polymorphisms involving sex chromosomes are commonly described in this group. Conversely, reports on numerical polymorphisms owing to the occurrence of supernumerary chromosomes are rare. To better understand the karyotype evolution of this group, we analyzed specimens of Parodon nasus collected in the Três Bocas/PR stream, applying different cytogenetic techniques. All individuals presented 54 meta-submetacentric chromosomes, except for three females, which exhibited structural polymorphism. The NOR occurred on a pair of submetacentric chromosomes. Heterochromatin was distributed in some pericentromeric areas, predominating in the terminal regions. We detected $B$ microchromosomes in four of the collected individuals, which were heterochromatic and bearers of $18 \mathrm{~S}$ rDNA sites. This work deals with the first description of these chromosomes in the family Parodontidae. The results indicate that, despite the conserved diploid number, this group of fish presents a more divergent karyotypic evolution, involving chromosome rearrangements in its karyotypic structure.
\end{abstract}

\section{ARTICLE HISTORY}

Received 8 October 2016 Accepted 10 April 2017

\section{KEYWORDS}

B chromosomes; 18S rDNA; heterochromatin; karyotype variation

\section{Introduction}

$\mathrm{B}$ chromosomes, also known as supernumerary or accessory chromosomes, are apparently dispensable genetic material that do not follow Mendel's law of segregation and are present in some individuals from some populations in some species. These chromosomes probably originated from the A complement, but followed a distinct evolutionary path, being found in different groups of plants and animals (Camacho et al. 2000).

In Neotropical fish, the occurrence of B chromosomes has been reported in 61 species distributed in 16 families from seven different orders. Characiformes is the group that comprises most species that present this genetic material (50.82\%), with 31 species distributed into six families (Carvalho et al. 2008).

Among the families of the order Characiformes, which have already had descriptions of supernumerary chromosomes, the family Parodontidae is the group with the least frequency of occurrence, presenting a single report of an extra chromosome in one individual of the species Apareiodon piracicabae (Falcão et al. 1984).

Unlike the occurrence of B chromosomes, rarely reported in the family Parodontidae, structural chromosomal abnormalities and deviations related to the presence of sex chromosomes are significantly recurrent.
Some studies have described multiple sex chromosome systems of the type ZZ/ZW ${ }_{1} \mathrm{~W}_{2}$ in Apareiodon affinis (Moreira-Filho et al. 1980; Jesus et al. 1999; Jorge and Moreira-Filho 2000; Bellafronte et al. 2011; Leite and Maistro 2004). On the other hand, Rosa et al. (2006) described single systems of the type ZZ/ZW in Apareiodon vladi; Vicari et al. (2006) in Apareiodon sp.; Jesus and Moreira-Filho (2000) in Parodon hilarii; and Centofante et al. (2002) in Parodon moreirai.

This study aims to investigate the karyotype and occurrence of chromosomal polymorphism in a population of Parodon nasus, utilizing different chromosome banding techniques, thereby contributing more information to improve the understanding of the karyotype evolution in the family Parodontidae.

\section{Material and methods}

Were analyzed nine females and seven males of Parodon nasus, collected in Três Bocas river, Londrina, Paraná, Brazil (23⒉ $23^{\prime} 7.25^{\prime \prime}$ S, 51 $\left.{ }^{\circ} 4^{\prime} 35.04^{\prime \prime} \mathrm{W}\right)$, Paranapanema river basin (Figure 1). The samples were collected with the permission of Instituto Brasileiro do Meio Ambiente e dos Recursos Naturais Renováveis (IBAMA), protocol number 11399-1. Specimens were deposited in the 


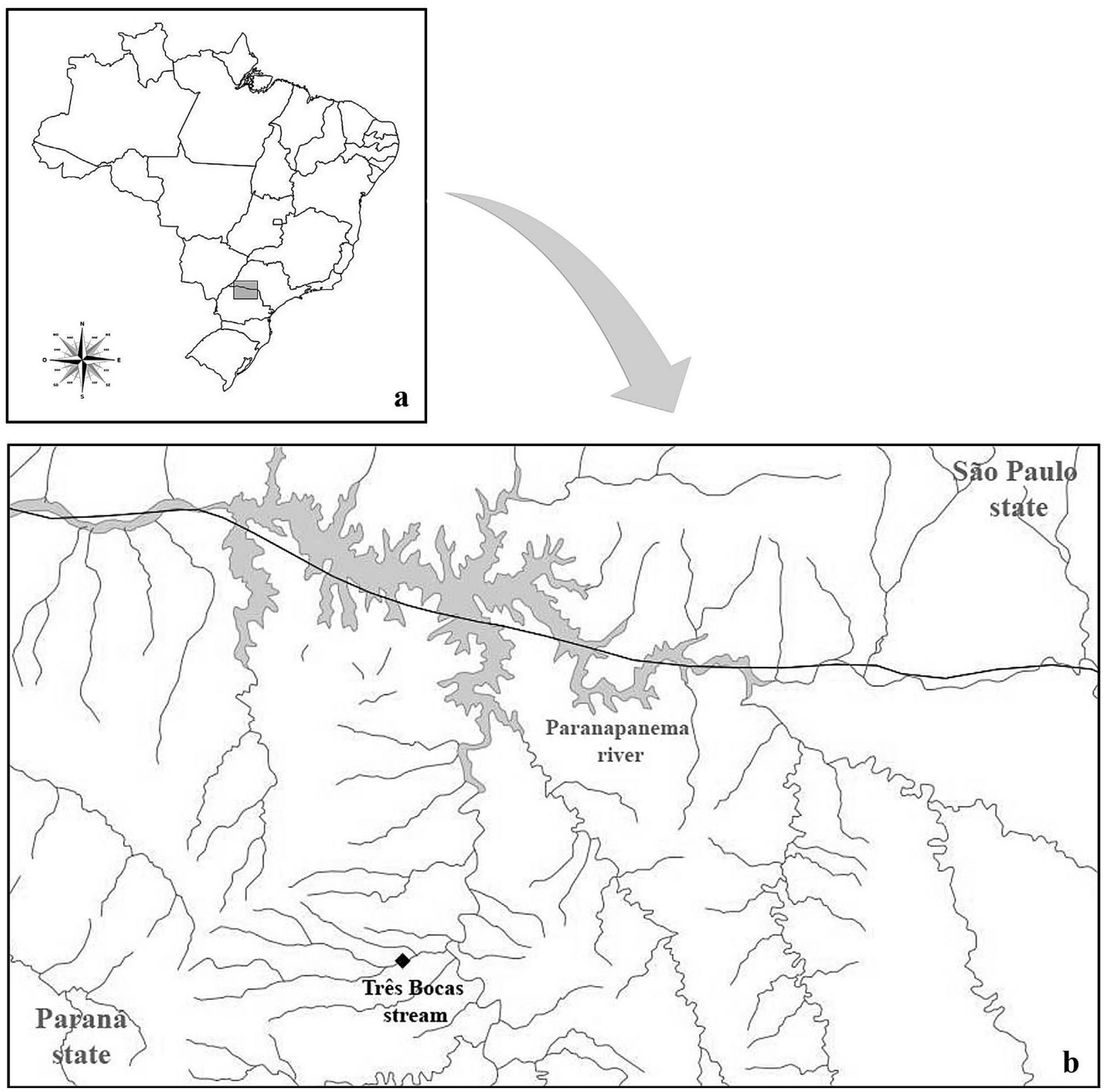

Figure 1. Collection site. Map of Brazil (a) indicating Três Bocas stream (b).

Museum of the Núcleo de Pesquisas em Limnologia, Ictiologia e Aquicultura of the Universidade Estadual de Maringá (NUPELIA-UEM).

Mitotic chromosomes were obtained by direct preparation after removal of the anterior kidney, as described by Bertollo et al. (1978). The chromosomes were organized in metacentric $(\mathrm{m})$ and submetacentric ( $\mathrm{sm}$ ) according to Levan et al. (1964) to determine the fundamental number $(\mathrm{FN})$ and were considered biarmed.

The distribution of heterochromatin was analyzed by C-banding (Sumner 1972). Silver nitrate staining of the active nucleolar organizer regions (AgNOR) was performed according to the method of Howell and Black (1980). The GC- and AT-rich bands were detected with chromomycin $\mathrm{A}_{3}\left(\mathrm{CMA}_{3}\right)$ and 4'-6-diamino-2phenylindole (DAPI), respectively, according to the technique described by Schweizer (1980). In addition, the fluorescence in situ hybridization (FISH) technique was carried out following the protocol reported by Pinkel et al. (1986) along with an $18 \mathrm{~S}$ rDNA probe obtained from Prochilodus argenteus (Hatanaka and Galetti 2004), labeled with biotin-14-dATP by nick translation. The hybridization signal was detected using avidin-FITC (fluorescein isothiocyanate) and the chromosomes were counterstained with propidium iodide. All the images were acquired with a Leica DM 4500 B microscope equipped with a DFC 300FX camera (Leica Microsystem, Germany) and Leica IM50 4.0 software (http://leica-im50.software.informer.com/4.0/), and optimized for best contrast and brightness with iGrafx Image software (http://www.igrafx.com/gl).

\section{Results}

All collected specimens presented $2 n=54$ meta-submetacentric (m-sm) chromosomes and fundamental number/FN=108, for both sexes (Figure 2(a)). However, in three females a heteromorphic pair was identified 


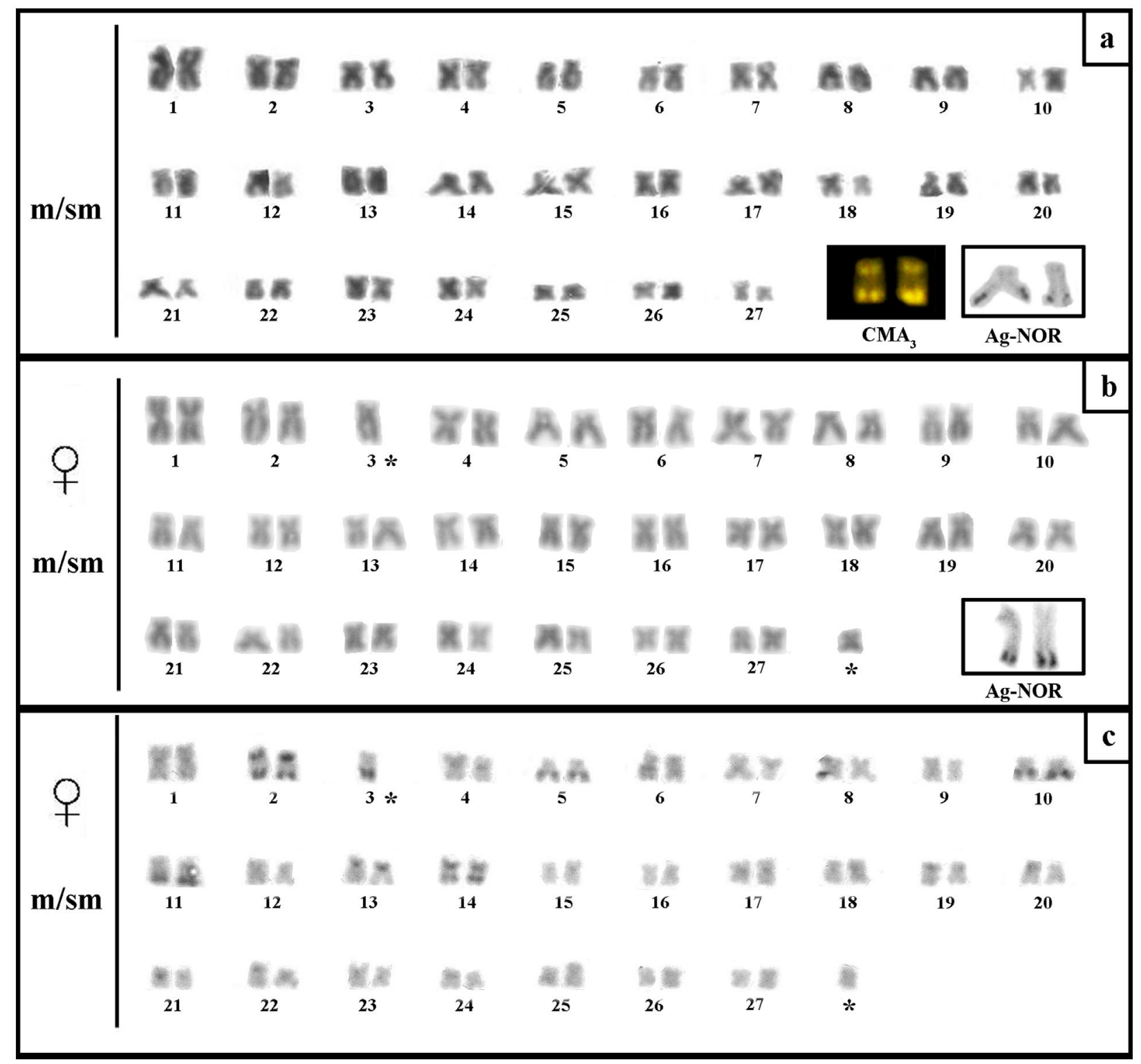

Figure 2. Karyotypes of Parodon nasus: (a) normal karyotype with conventional staining to males and females; (b) and (c) females with structural polymorphism of pair 3 (indicated by asterisk) with conventional staining and C banding respectively. In the box, chromosomal pair with $\mathrm{CMA}_{3}$ and AgNOR regions.

(recognized as par 3) consisting of a very large submetacentric chromosome and its presumed homolog by a small metacentric chromosome (Figure 2(b)).

Among the 16 individuals analyzed, four individuals (three females and one male) presented supernumerary microchromosomes or Bs, whose occurrence varied from 0 to 4 (Table 1). The frequency of cells with B chromosomes in each individual is very variable, representing from $25 \%$ (specimen no. 4370) to more than $50 \%$ (specimen no. 4169) of the cells analyzed. In these four individuals we assessed 164 metaphases, with one B chromosome (27.44\%), and two (12.19\%), three (3.66\%), and four supernumerary chromosomes $(0.61 \%)$. We did not observe B chromosomes in 92 of the metaphases (56.10\%) (Table 1).

The Ag-NORs occupied the terminal region on the long arm of a pair of submetacentric chromosomes
Table 1. B chromosome frequency in somatic cell of Parodon nasus from Três Bocas stream.

\begin{tabular}{lccccccc}
\hline & & \multicolumn{7}{c}{ Number of B chromosomes } & Number \\
\cline { 3 - 7 } Specimens & Sex & 0 & 1 & 2 & 3 & 4 & of cells \\
\hline 4169 & 1 & 15 & 10 & 5 & 1 & - & 31 \\
4367 & + & 25 & 13 & 7 & 1 & - & 46 \\
4368 & + & 28 & 15 & 7 & 4 & 1 & 55 \\
4370 & + & 24 & 7 & 1 & - & - & 32 \\
& Total & 92 & 45 & 20 & 6 & 1 & 164 \\
& $\%$ & 56.10 & 27.44 & 12.19 & 3.66 & 0.61 & \\
\hline
\end{tabular}

(Figure 2(a-box)), with size heteromorphism between the homologous chromosomes in most specimens, evidenced after FISH with an $18 \mathrm{~S}$ rDNA probe (Figure 3(a)). However, four individuals that presented B microchromosomes did not exhibit heteromorphism either after silver impregnation (Figure 2(b - box)) or FISH (Figure 3(b)). 

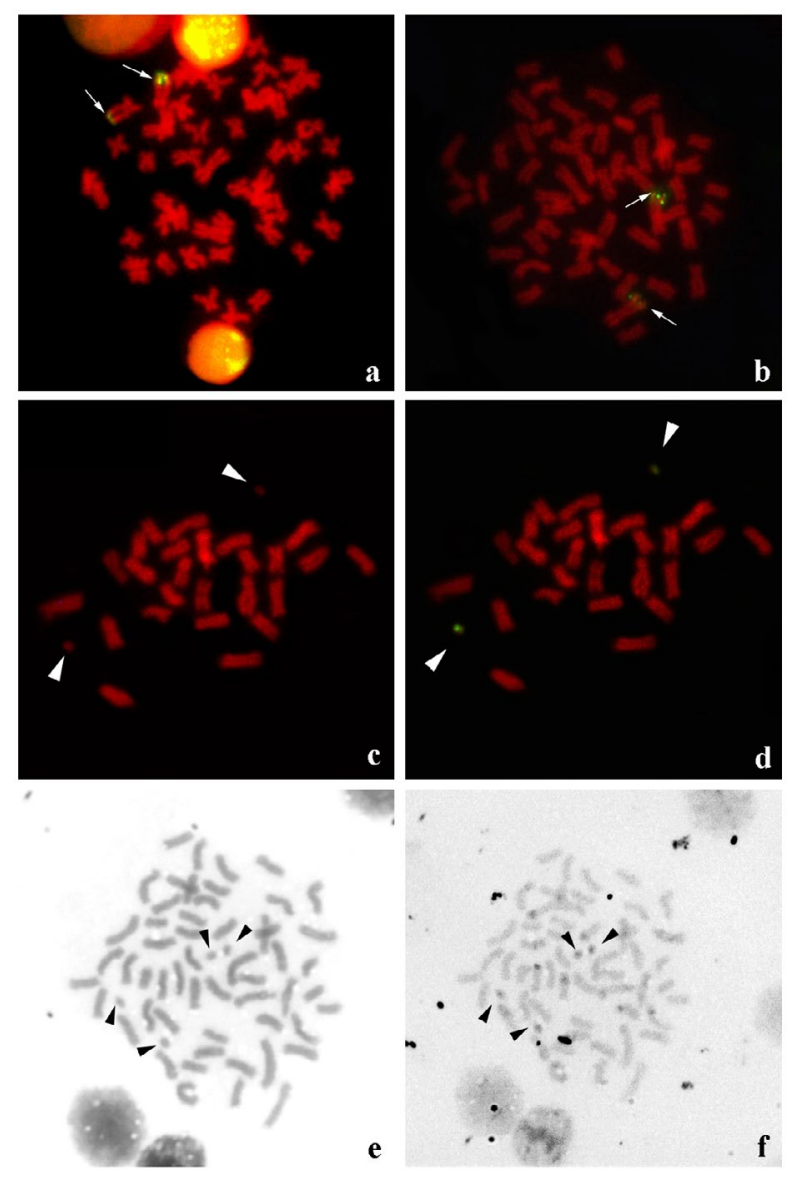

Figure 3. Somatic metaphases of Parodon nasus with fluorescence in situ hybridization (FISH) (a, b, c, d), Giemsa staining (e) and $\mathrm{C}$ banding (f). The arrows indicate $18 \mathrm{~S}$ rDNA sites in (a) with heteromorphism size, and in (b), without heteromorphism size; the arrowheads indicate B chromosomes without and with $18 \mathrm{~S}$ rDNA site (c, d, respectively). The arrowheads in (e) and (f) indicate the heterochromatic $B$ chromosomes.

The NORs were coincident with GC-rich regions in all individuals (Figure 2(a)) and 18S rDNA sites were detected in B chromosomes (Figure 3(d)).

All individuals, except for those carrying the B chromosomes, exhibit the ribosomal clusters in a terminal region on the long arm of a pair of submetacentric chromosomes (Figure 2(a - box)), with size heteromorphism between the homologous chromosomes evidenced by AgNOR and FISH with an 18S rDNA probe (Figure 3(a)). In these individuals the NORs were coincident with GC rich regions (Figure 2(a)). However, the four individuals that presented $\mathrm{B}$ chromosomes did not exhibit heteromorphism in a submetacentric pair (Figure 2(b - box) and Figure 3(b)) and the 18S rDNA sites were detected in B chromosomes (Figure 3(c) and 3(d)).

C-heterochromatic blocks on some pericentromeric regions are observed, and also in terminal regions (Figure 2(c)). The B microchromosomes were heterochromatic (Figure 3(e) and 3(f)) and the non-homologous submetacentric chromosome of the females with a karyotype formula of $52 \mathrm{~m}$-sm $+1 \mathrm{sm}+1 \mathrm{~m}$ presented a heterochromatic block in the terminal portion of the long arm (Figure 2(c)).

\section{Discussion}

Individuals of Parodon nasus from Três Bocas stream displayed 54 meta-submetacentric chromosomes, but did not show subtelocentric chromosomes, as described in other populations by Jesus and Moreira-Filho (2000), Vicente et al. (2001), Centofante et al. (2002), Bellafronte et al. (2005). According to Schemberger et al. (2011) the hypothetical ancestor of the Parodontidae family is characterized by a karyotype formula of $2 n=54 \mathrm{~m} / \mathrm{sm}$ chromosomes. Probably, in P. nasus from Três Bocas stream, no chromosome rearrangement occurred during its process of evolution, so this is the first report of this karyotype structure in this species.

Three females demonstrated a structural chromosome variation not previously reported in Parodon nasus. A possible origin of this heteromorphism could have been a deletion, occurring in the terminal portion of the long arm of one of the homologous chromosomes of submetacentric pair 3 , yielding a smaller metacentric chromosome with the absence of heterochromatin at the terminal portion.

Specimens of Parodon nasus were subjected to fluorescent in situ hybridization with a repetitive DNA probe from the $\mathrm{W}$ sex chromosome from Apareiodon ibitiensis (WAp FISH) by Schemberger et al. (2011) and proximal hybridization and terminal sites were detected on the short arm of metacentric chromosome pair 13, therefore this chromosome was considered a proto-sex chromosome within the family Parodontidae.

The occurrence of sex chromosomes of the type ZZ/ ZW has been reported in species of the genus Parodon, as P. hilarii and P. moreirai (Moreira-Filho et al. 1993; Jesus and Moreira-Filho 2000; Centofante et al. 2002; Schemberger et al. 2011). Notwithstanding, further analysis of FISH with specific probes as the WAp FISH utilized by Schemberger et al. (2011) can confirm or not if this heteromorphism in the population of the Três Bocas stream is related to sex determination.

Bellafronte et al. (2011) observed that Parodon nasus is the only species of the genus to present $18 \mathrm{~S}$ rDNA sites on a subtelocentric, rather than on a submetacentric pair. In this study, however, we observed AgNORs of Parodon nasus on the long arm of submetacentric pair 2, coincident with the $18 \mathrm{~S}$ rDNA sites. Cytogenetic studies in other populations of the species indicate the location of NORs on subtelocentric pair 25 (Jesus and Moreira-Filho 2000; Vicente et al. 2001; Centofante et al. 2002; Bellafronte et al. 2005).

Like Parodon nasus in the present study, Parodon pongoensis analyzed by Bellafronte et al. (2011) has $18 \mathrm{~S}$ rDNA sites in the terminal portion of the long arm of submetacentric pair 2. According to Schemberger 
et al. (2011), P. nasus and P. pongoensis can be considered homomorphic species, due to the presence of a pair of proto-sex chromosomes. However, both are clearly differentiated by the synteny between $18 \mathrm{~s}$ and $5 \mathrm{~s}$ rDNA present only in Parodon nasus, an apomorphic character within the family Parodontidae, that originated from a chromosomal translocation event (Bellafronte et al. 2011).

The occurrence of $18 \mathrm{~S}$ rDNA sites is somewhat rare in accessory chromosomes. It was described in Astyanax paranae, order Characiformes (Silva et al. 2014), Pimelodella sp., order Siluriformes (Garcia and Toledo 2010), Astatotilapia latifasciata (Fantinatti et al. 2011) and Haplochromis obliquidens, order Perciformes (Poletto et al. 2010). Active nucleolar sites were found on B microchromosomes of Moenkhausia sanctaefilomenae (Hashimoto et al. 2012), which is the only report of ribosomal DNA in microchromosomes.

Camacho et al. (2000) support that B chromosomes may be considered products of the evolution of the A complement. Thus, the origin of these B microchromosomes in Parodon nasus is likely to have resulted from a deletion of genetic material from a specific region on the long arm of one of the chromosomes of pair 2, since individuals with Bs were not heteromorphic for the $18 \mathrm{~S}$ rDNA sites, differing from other individuals in the population.

Another fact that might corroborate the probable origin of $\mathrm{B}$ microchromosomes in this population is that the terminal portion of pair 2 shows heterochromatin adjacent to $18 \mathrm{~S}$ rDNA sites, a feature also revealed for Bs.

Schemberger et al. (2011) corroborate that the hypothetical ancestor of the family Parodontidae has a karyotype formula of $2 n=54 \mathrm{~m} / \mathrm{sm}$ chromosomes, little heterochromatin in the proximal and distal regions, a terminal NOR on a metacentric pair and the absence of heteromorphic sex chromosomes. Therefore, the population of Parodon nasus in this study presents characteristics that resemble this ancestor. However, the structural and numerical polymorphisms detected suggest that the species of this family are constantly evolving, and, despite the conserved diploid number, the karyotypic evolution in the family Parodontidae is more divergent than conservative.

\section{Acknowledgments}

The authors are grateful to the Instituto Brasileiro do Meio Ambiente e Recursos Naturais Renováveis (MMA/IBAMA) for authorizing the fish collections, Fundação Araucária and Conselho Nacional de Desenvolvimento Científico e Tecnológico for their financial support and Carla Simone Pavanelli (NUPELIA-UEM) for identifying the specimens.

\section{Disclosure statement}

No potential conflict of interest was reported by the authors.

\section{Funding}

This work was supported by the Conselho Nacional de Desenvolvimento Científico e Tecnológico under [grant number 507681/2010-0].

\section{ORCID}

Lucia Giuliano-Caetano (D) http://orcid.org/0000-0002-86762852

\section{References}

Bellafronte E, Margarido VP, Moreira-Filho O. 2005. Cytotaxonomy of Parodon nasus and Parodon tortuosus (Pisces, Characiformes). A case of synonymy confirmed by cytogenetic analyses. Genet Mol Biol. 28:710-716.

Bellafronte E, Schemberger MO, Moreira-Filho O, Almeida MC, Artoni RF, Margarido VP, Vicari MR. 2011. Chromosomal markers in Parodontidae: an analysis of new and reviewed data with phylogenetic inferences. Rev Fish Biol Fish. 21:559-570.

Bertollo LAC, Takahashi CS, Moreira-Filho O. 1978. Cytotaxonomic considerations on Hoplias lacerdae (Pisces, Erythrinidae). Braz J Genet. 1:103-120.

Camacho JP, Sharbel TF, Beukeboom LW. 2000. B-chromosome evolution. Philos Trans R Soc London B Biol Sci. 355:163-178.

Carvalho RA, Martins-Santos IC, Dias AL. 2008. B chromosomes: an update about their occurrence in freshwater Neotropical fishes (Teleostei). J Fish Biol. 72:1907-1932.

Centofante L, Bertollo LAC, Moreira-Filho O. 2002. A ZZ/ ZW sex chromosome system in a new species of the genus Parodon (Pisces, Parodontidae). Caryologia. 55:139-150.

Falcao JD, Moreira-Filho O, Bertollo LAC. 1984. An additional chromosome in two fish species. Rev Bras Genet. 7:109-118.

Fantinatti BEA, Mazzuchelli J, Valente GT, Cabral-de-Mello DC, Martins C. 2011. Genomic content and new insights on the origin of the $\mathrm{B}$ chromosome of the cichlid fish Astatotilapia latifasciata. Genetica. 139:1273-1282.

Garcia C, Toledo LFD. 2010. Comparative chromosomal analyses in species of the genus Pimelodella (Siluriformes, Heptapteridae): occurrence of structural and numerical polymorphisms. Caryologia. 63:32-40.

Hashimoto DT, Voltolin TA, Paes ADNVD, Foresti F, Bortolozzi J, Porto-Foresti F. 2012. Cytogenetic analysis of B chromosomes in one population of the fish Moenkhausia sanctaefilomenae (Steindachner, 1907) (Teleostei, Characiformes). Comp Cytogenet. 6:141-151.

Hatanaka T, Galetti PM. 2004. Mapping of the 18S and 5S ribosomal RNA genes in the fish Prochilodus argenteus Agassiz, 1829 (Characiformes, Prochilodontidae). Genetica. 122:239-244.

Howell WM, Black DA. 1980. Controlled silver-staining of nucleolus organizer regions with a protective colloidal developer: a 1-step method. Experientia. 36:1014-1015.

Jesus CM, Bertollo LAC, Moreira-Filho O. 1999. Comparative cytogenetics in Apareiodon affinis (Pisces, Characiformes) and considerations regarding diversification of the group. Genetica. 105:63-67.

Jesus CM, Moreira-Filho O. 2000. Karyotypes of three species of Parodon (Teleostei: Parodontidae). Ichthyol Explor Freshw. 11:75-80. 
Jorge LC, Moreira-Filho O. 2000. Cytogenetic studies on Apareiodon affinis (Pisces, Characiformes) from Parana river basin: sex chromosomes and polymorphism. Genetica. 109:267-273.

Leite MF, Maistro EL. 2004. The karyotype of Apareiodon affinis (Pisces, Teleistei, Characiformes) from Sapucaí river, Minas Gerais, Brazil. Cytologia. 69:319-322.

Levan A, Fredga K, Sandberg AA. 1964. Nomenclature for centromeric position on chromosomes. Hereditas. 52:201-220.

Moreira-Filho O, Bertollo LAC, Galetti PM. 1980. Evidences for a multiple sex-chromosome system with female heterogamety in Apareiodon affinis (Pisces, Parodontidae). Caryologia. 33:83-91.

Moreira-Filho O, Bertollo LAC, Galetti PM. 1993. Distribution of sex chromosome mechanisms in neotropical fish and description of a ZZ/ZW system in Parodon hilarii (Parodontidae). Caryologia. 46:115-125.

Pinkel D, Straume T, Gray JW. 1986. Cytogenetic analysis using quantitative, high-sensitivity, fluorescence hybridization. Proc Natl Acad Sci. 83:2934-2938.

Poletto AB, Ferreira IA, Martins C. 2010. The B chromosomes of the African cichlid fish Haplochromis obliquidens harbour 18S rRNA gene copies. BMC Genet. 11:1-8.

Rosa R, Bellafronte E, Moreira-Filho O, Margarido VP. 2006. Constitutive heterochromatin, 5S and 18S rDNA genes in Apareiodon sp. (Characiformes, Parodontidae) with a ZZ/ ZW sex chromosome system. Genetica. 128:159-166.
Schemberger MO, Bellafronte E, Nogaroto V, Almeida MC, Schuhli GS, Artoni RF, Moreira O, Vicari MR. 2011. Differentiation of repetitive DNA sites and sex chromosome systems reveal closely related group in Parodontidae (Actinopterygii: Characiformes). Genetica. 139:1499-1508.

Schweizer D. 1980. Simultaneous fluorescent staining of r-bands and specific heterochromatic regions (da-dapi bands) in human-chromosomes. Cytogenet Cell Genet. 27:190-193.

Silva DMZD, Pansonato-Alves JC, Utsunomia R, ArayaJaime C, Ruiz-Ruano FJ, Daniel SN, Hashimoto DT, Oliveira C, Camacho JPM, Porto-Foresti F, Foresti F. 2014. Delimiting the origin of a $\mathrm{B}$ chromosome by FISH mapping, chromosome painting and DNA sequence analysis in Astyanax paranae (Teleostei, Characiformes). PLoS One. 9(4):e94896. doi: 10.1371/journal.pone.0094896.

Sumner AT. 1972. Simple technique for demonstrating centromeric heterochromatin. Exp Cell Res. 75:304-306.

Vicari MR, Moreira-Filho O, Artoni RF, Bertollo LAC. 2006. ZZ/ZW sex chromosome system in an undescribed species of the genus Apareiodon (Characiformes, Parodontidae). Cytogenet Genome Res. 114:163-168.

Vicente VE, De Jesus CM, Moreira-Filho O. 2001. Chromosomal localization of 5S and 18S rRNA genes in three Parodon species (Pisces, Parodontidae). Caryologia. 54:365-369. 